\title{
Growth and reproductive characteristics of rarely observed resident female Dolly Varden (Salvelinus malma malma) in North America
}

\author{
Colin P. Gallagher • Christie M. Morrison • Ellen V. Lea • Norman M. Halden • \\ Kimberly L. Howland
}

Received: 20 July 2018/Revised: 11 February 2019/Accepted: 1 March 2019/Published online: 14 March 2019

(C) The Author(s) 2019

\begin{abstract}
Among North American populations of northern form Dolly Varden (Salvelinus malma malma) exhibiting partial migration, the resident female life history is rarely encountered. Between 2012 and 2016, three sexually mature females confirmed as residents using otolith strontium analysis were captured from three rivers in the western Canadian Arctic ( $<1 \%$ of residents sampled). Sizeat-capture and size-at-age, estimated using otolith back-calculation, were compared to resident males and anadromous females. Fecundity, egg diameter, and gonadosomatic index (GSI) were compared to anadromous female current-year spawners. Resident females (fork length range $220-360 \mathrm{~mm}$ ) tended to be among the largest-sized residents (two were $>90$ th
\end{abstract}

Guest editors: C. E. Adams, C. R. Bronte, M. J. Hansen, R. Knudsen \& M. Power / Charr Biology, Ecology and Management

C. P. Gallagher $(\varangle)$ - C. M. Morrison - K. L. Howland Fisheries and Oceans Canada, 501 University Crescent, Winnipeg, MB R3T 2N6, Canada e-mail: colin.gallagher@dfo-mpo.gc.ca

E. V. Lea

Fisheries and Oceans Canada, P.O. Box 1871, Inuvik, NT X0E 0T0, Canada

\section{N. M. Halden}

Department of Geological Sciences, University of Manitoba, 125 Dysart Road, Winnipeg, MB R3T-2N2, Canada percentile). Early size-at-age of resident females either exceeded or were among the largest sizes compared to resident males and pre-smolt anadromous females. Residents had similar fecundity predicted for length and egg size (range 3.5-4.2 $\mathrm{mm}$ ) compared to anadromous, although GSI (range 13.2-17.4\%) was inconsistent among populations. Interestingly, one resident female attained a greater size-at-capture and fecundity than the smallest anadromous current-year spawner. Our results suggest that conditional mating tactics of Dolly Varden can be expressed by both sexes in multiple populations, and increases understanding of Dolly Varden life history diversity and bet-hedging strategies in partially migratory populations.

Keywords Salvelinus malma $\cdot$ Female $\cdot$ Life history $\cdot$ Alternative reproductive tactics $\cdot$ Partial migration $\cdot$ Trade-offs

\section{Introduction}

Characterizing patterns of reproductive investment and behaviour in fishes informs life history models that are useful for predicting fitness (lifetime breeding success) and are relevant for conservation and management of life history diversity (Thorpe et al., 1998; Mangel \& Satterthwaite, 2008). In fishes of the family Salmonidae, investment in reproduction can be highly variable among species and within populations 
(Fleming \& Reynolds, 2004). The optimal allocation of energy towards reproduction is a function of tradeoffs that maximize fitness that is partly driven by differences in the variance in breeding successes (i.e., measure of opportunity for selection during reproduction) between the sexes (Clutton-Brock, 1988; Fleming \& Reynolds, 2004). Specifically, female fitness is a function of egg production (i.e., number of offspring produced) and probability of offspring survival (e.g., egg size) (Jonsson \& Jonsson, 1993; Quinn et al., 2004). Although negatively correlated, fecundity and egg size are both positively correlated with length, which favours female behaviour resulting in increased size (Fleming, 1996; Einum et al., 2004; Fleming \& Reynolds, 2004). In males, success is a function of access to females and the number of eggs fertilized, which are not necessarily related to body size (Fleming \& Reynolds, 2004).

Anadromous behaviour strongly influences individual growth and size among salmonid populations in freshwater habitats with access to the sea, which allows fish to capitalize on energy sources in relatively productive marine environments (Jonsson \& Jonsson, 1993). Benefits of migration include greater size, energy stores, and reproductive output at maturity, while costs associated with migration include older age-at-maturity and an increased probability of mortality, particularly for populations enduring long and or arduous journeys (Hendry et al., 2004). Similar to reproductive investment, migration tactics vary among species and within populations, where the variation in migration tendencies reflects differential costs and benefits for each population (Hendry et al., 2004). Within populations, migration dimorphism may arise ('partial migration'; Chapman et al., 2011), where one segment undertakes ocean feeding migration(s) while the other remains a life-long resident of freshwater habitat. Both tactics produce different phenotypes (i.e., smaller-sized resident and larger-sized migrant) and alternative reproductive behaviours (e.g., 'sneaker' in resident and 'fighter' in anadromous males), yet tend to share a common gene pool (e.g., Pettersson et al., 2001; Moore et al., 2014; Harris et al., 2015). Because costs and benefits of migration differ between sexes (Hendry et al., 2004 and references therein), this helps explain why anadromous and resident life histories are biased towards females and males, respectively, in populations exhibiting partial migration (Jonsson \& Jonsson, 1993). Co-existence of resident and anadromous males in a single population has been explained as alternative tactics within a conditional mating strategy maintained in frequency-dependent (i.e., number of alternative phenotypes present in a population) and condition-dependent (i.e., individual competitive ability) selection during reproduction (Gross, 1996; Gross \& Repka, 1998; Berejikian et al., 2010). Adopting either migratory or reproductive tactic is likely influenced by a combination of factors, including polygenic traits controlling age at maturity, and metabolic and environmental factors (e.g., its effect on food availability) affecting growth thresholds (e.g., increased growth at an early age) that allow individuals to mature early without resorting to anadromy (Fleming, 1996; Gross, 1996; Forseth et al., 1999; Wysujack et al., 2009).

In salmonine (sub-family Salmoninae) populations exhibiting partial migration, the resident female has been documented in multiple species and populations (Prouzet, 1981; Johnsson, 1985; Hindar \& Nordland, 1989; O’Connell \& Gibson, 1989; Vespoor \& Cole, 1989; Hutchings, 1986; Rikardsen \& Elliott, 2000; Jonsson et al., 2001; Thériault et al., 2007; Wysujack et al., 2009; Loewen et al., 2010; Mills et al., 2012; Kendall et al., 2014; Salisbury et al., 2018), including Dolly Varden (Salvelinus malma (Walbaum)). Resident female Dolly Varden have been found in the subspecies (see Phillips et al., 1999) S. m. krascheninnikovi inhabiting the Island of Hokkaido in Japan (Koizumi et al., 2006). Alternatively, life-long resident females have rarely been documented in partially migratory populations of the subspecies $S$. m. malma and $S . m$. lordi. The resident female of the northern form (S. m. malma) has been found on the Kamchatka Peninsula (Russia) (Gruzdeva et al., 2017). In North America, resident females $(n=11)$ were found in a putatively admixed population of $S$. m. malma and $S$. $m$. lordi (Taylor \& May-McNally, 2015) in the Chignik Lake watershed (Alaska Peninsula, Alaska, U.S.A.) which drains into the Gulf of Alaska (Bond et al., 2015). Among exclusively northern form populations in North America, sexually mature purportedly resident females have only been noted in rivers north of the Arctic Circle in the Alaska (U.S.A) and Yukon (Canada) North Slope. Specifically, only two in the Canning River drainage, Alaska (Craig, 
1977) and "some" in Fish Creek, Yukon Territory (Craig \& McCart, 1976) based on sampling conducted in the early 1970s. No biological data were reported for purported resident females apart from length, age, and mean egg diameter of the Canning River specimens. The incidence of resident females was described as 'extremely small' (Craig, 1977, p. 69), given that resident males are common among 12 North Slope river systems draining into the Beaufort Sea inhabited by partially migratory Dolly Varden (Bain, 1974; Glova \& McCart, 1974; Craig, 1978; McCart, 1980; Reist, 1989; Gallagher et al., 2012). It should be noted that the early literature on Dolly Varden along the North Slope referred to the species as Arctic charr $(S$. alpinus (L.)) until confirmed as Dolly Varden (Reist et al., 1997).

In Canada, populations of anadromous northern form Dolly Varden are genetically differentiated among river systems and highly philopatric (Harris et al., 2015). All known river systems in Canada supporting the anadromous life history are also inhabited by the resident life history. Both resident and anadromous are sympatric when occupying freshwater (i.e., spawning and overwintering) and resident males breed with anadromous females given the two life histories do not differ genetically within river systems (Harris et al., 2015). Both life histories differ phenotypically in size and colouration (see Armstrong \& Morrow, 1980; COSEWIC, 2010).

Dolly Varden demonstrate intense breeding competition based on the energetic investment by anadromous males into secondary sexual characters (e.g., vivid colouration, development of kype and dorsal hump, and laterally flattened body) and defending territory in geographically limited optimal spawning habitat (e.g., Armstrong \& Morrow, 1980; Maekwa et al., 1993). During reproduction, resident males adopt a 'sneaker' strategy to spawn with anadromous females that are defended by anadromous males. In the Arctic, spawning occurs in autumn (approximately mid-September to October) and anadromous individuals can spawn in consecutive or alternate years within a population (Gallagher et al., 2018a, b). Spawning and overwintering habitats are inextricably linked in alpine headwater reaches in areas associated with perennial ground-water springs that maintain unfrozen stretches of river throughout winter (Mochnacz et al., 2010).
Juveniles rear in freshwater streams until a component of these begin annual seasonal migrations between freshwater spawning/overwintering and marine feeding habitats upon smoltification (first time to sea) (typically starting between ages 2-5; Gallagher et al., 2018a). The resident is typically smaller $(150-350 \mathrm{~mm})$ than the anadromous life history (250-800 mm fork length). Anadromous males attain larger sizes and grow faster than females (DFO, 2017). Dolly Varden are relatively short-lived because few survive beyond 10 years of age (Armstrong \& Morrow, 1980). There are isolated populations of Dolly Varden comprised of small-sized (typically $<300 \mathrm{~mm}$ ) males and females, residing above impassable falls in watersheds otherwise occupied by partially migratory populations. In Canada, isolated populations are found in Little Fish Creek, a tributary to the Big Fish River (McCart \& Bain, 1974), and in the Babbage River (Bain, 1974). Isolated and partially migratory populations are genetically distinct from one another (Harris et al., 2015).

Three sexually mature females with a phenotype similar to resident males were observed in three different river systems while conducting annual sampling programmes for Dolly Varden in the western Canadian Arctic in recent years. Our objectives were to determine if: (1) the three fish remained in freshwater throughout their lives by measurement of otolith strontium (Sr); (2) relative abundance of resident females was 'extremely small' as described by Craig (1977); (3) resident females and males were similar in size-at-capture and estimated size-at-age; and (4) females traded off size-at-capture, size-at-age, and reproductive characteristics for adopting either a resident or anadromous life history. Although the low sample size excluded the possibility of robust statistical analyses, results would inform how investment in growth and reproduction, and associated trade-offs, influenced female life history in partially migratory populations. Results would be the first comprehensive reporting of biological characteristics of the rarely observed female stream resident northern form Dolly Varden in North America. Documenting the diversity of life histories exhibited within populations of the genus Salvelinus is relevant for conservation objectives (Reist et al., 2013), which is pertinent given the northern form Dolly Varden is listed as a species of 'special concern' under the Species at Risk Act in Canada. 


\section{Materials and methods}

\section{Study locations}

Resident Dolly Varden were captured while conducting annual fisheries surveys targeting the anadromous life history in Fish Hole Creek and Fish Creek, spawning tributaries of the Babbage River and Rat River, respectively, and in Fish Creek (same location mentioned by Craig \& McCart, 1976) in Ivvavik National Park (INP) (a different creek $230 \mathrm{~km}$ west of the Fish Creek draining into the Rat River), each in the Yukon Territory, Canada (Fig. 1). For clarity, the two homonymous systems will be referred as Fish Creek
(Rat R.) and Fish Creek (INP). Prior to 2013, fisheries investigations in Fish Creek (Rat R.) during spawning were only conducted in the lower reach $\sim 0.7$ river $\mathrm{km}$ above the confluence with the Rat River and rarely encountered residents (Sandstrom et al., 2009). Starting in 2013, sampling was expanded to include a stretch of the headwater of Fish Creek (Rat R.) west of the Yukon Territory-Northwest Territories border and $\sim 28$ river $\mathrm{km}$ upstream of past surveys where a relatively high density of residents was detected. The distance between freshwater spawning and overwintering, and marine feeding habitats used by the anadromous life history is 317 river $\mathrm{km}$ and 22 river $\mathrm{km}$ for the Rat River and Fish Creek (INP)

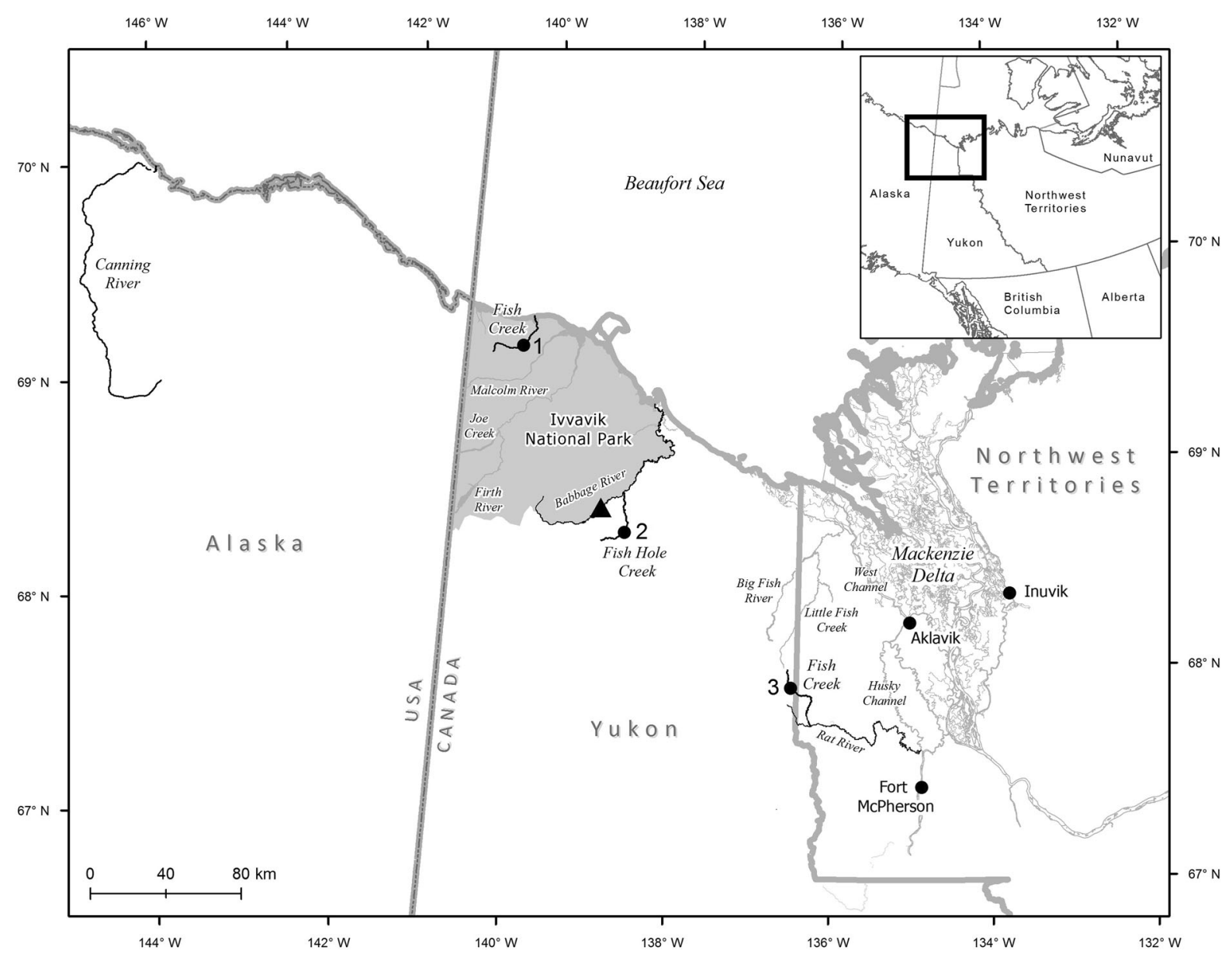

Fig. 1 Map of study area illustrating the three river systems where current-year spawning resident female Dolly Varden have been captured (closed numbered circles) in the Yukon Territory, Canada between 2012 and 2016. The triangle on the Babbage River denotes an impassable waterfall above which resides a population of the isolated life history of Dolly Varden. Resident females were also reported by Craig \& McCart (1976) and Craig (1977) while sampling in Fish Creek (Ivvavik National Park), Yukon Territory and Canning River, Alaska, respectively in the early 1970 s 
populations, which are among the longest and shortest, respectively, for northern form Dolly Varden in North America. The distance for the Babbage River population is 145 river $\mathrm{km}$.

\section{Sample collections}

Residents were incidentally captured using the same seine (40-mm stretched nylon mesh) described by Sandstrom et al. (2009) in areas used by anadromous Dolly Varden for spawning in mid- to late September. Resident and anadromous life histories were captured concurrently in each river system. Annual sampling (where both life histories were captured with the same net) was conducted in Fish Hole Creek between 2010 and 2017, in Fish Creek (Rat R.) between 2013 and 2017 (except in 2016), and in Fish Creek (INP) in 2016 and 2017. The same areas of geographically limited spawning grounds were consistently sampled among years for the three locations. Each Dolly Varden captured in the seine was assigned to a life history category (resident or anadromous) and measured for fork length. In addition, reproductive status of anadromous fishes (non-spawner or spawner) and sex of fishes in spawning condition (male or female) were recorded. Anadromous non-spawners were either juveniles or resting adults (sex unknown) that retained silver marine phase colouration. Distinct colouration among residents, and male and female anadromous spawners (see images in Fig. 2) and non-spawners produced very high confidence in visual assignments of life history, sex, and reproductive status. The three sexually mature purported resident females were captured in Fish Hole Creek in 2012, Fish Creek (Rat R.) in 2014, and Fish Creek (INP) in 2016 (Table 1).

Among years and river systems, residents were dead- and live-sampled. In Fish Hole Creek, 124 residents were captured, of which 110 were deadsampled. In Fish Creek (Rat R.), 256 residents were captured, of which 71 were dead-sampled. In Fish Creek (INP), 485 residents were sampled, of which 59 were dead-sampled. The ventral surface of livesampled residents was lightly squeezed to confirm sex and reproductive status (milt was expelled) prior to release while dead-sampled residents were processed in a laboratory. Dead-sampled residents were measured $( \pm 1 \mathrm{~mm})$ and weighed $( \pm 1 \mathrm{~g})$, otoliths were
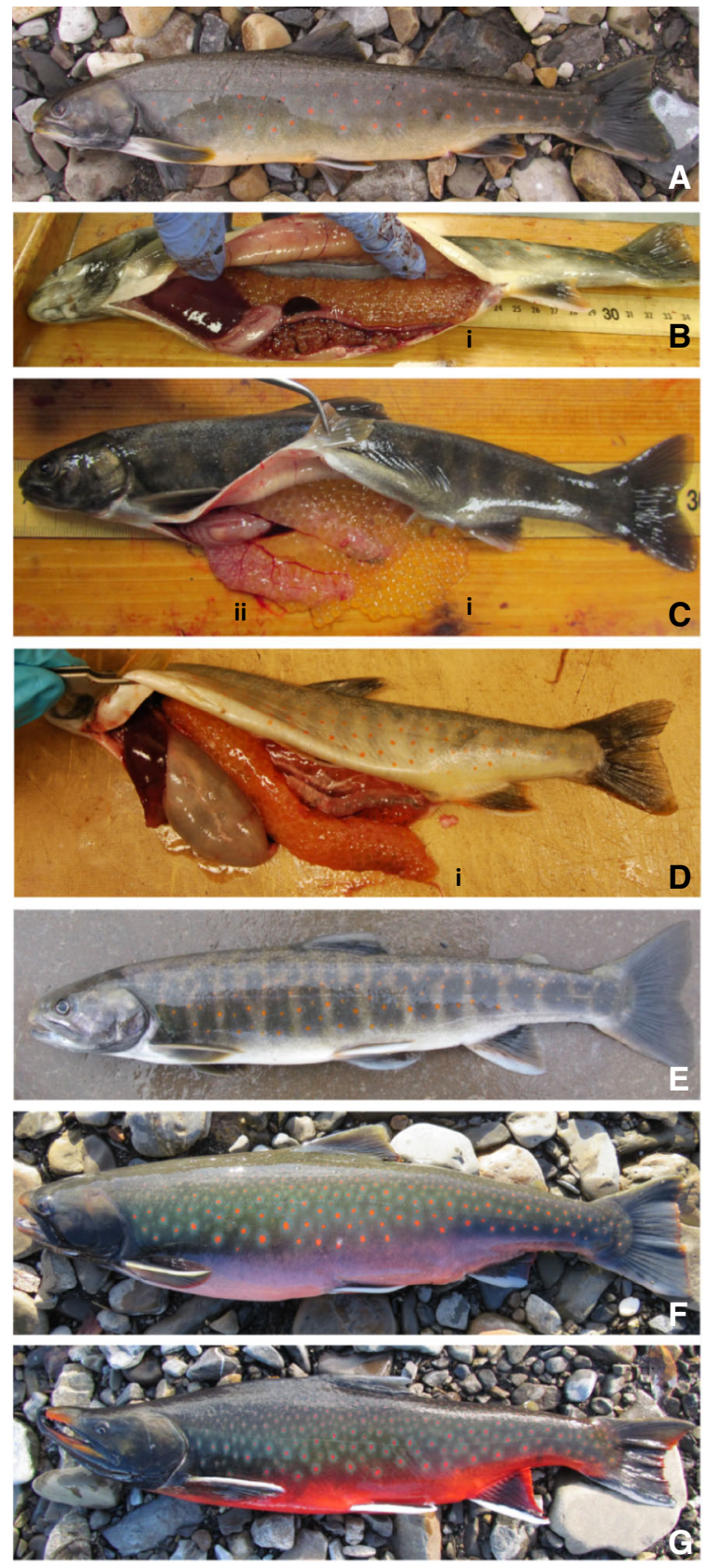

Fig. 2 Image of resident female Dolly Varden captured at A, B Fish Hole Creek (same fish) (Babbage River population) (FL $=360 \mathrm{~mm}$ ), C Fish Creek (Rat River population) (FL = $220 \mathrm{~mm}$ ), and D Fish Creek (in Ivvavik National Park) $(\mathrm{FL}=269 \mathrm{~mm})$. Phenotype of $\mathbf{E}$ resident male $(\mathrm{FL}=250 \mathrm{~mm})$, $\mathbf{F}$ anadromous female $(\mathrm{FL}=560 \mathrm{~mm})$, and $\mathbf{G}$ anadromous male $(\mathrm{FL}=620 \mathrm{~mm}$ ) in spawning condition shown for comparative purposes. Note image in $\mathbf{B}, \mathbf{C}, \mathbf{D}$ shows (i) ripe eggs (mature oocytes) and C (ii) immature oocytes (1 $\mathrm{mm}$ diameter) in an ovary membrane. $F L$ fork length 
Table 1 Biological information of three current-year spawning resident female Dolly Varden captured among river systems in the Yukon Territory, Canada between 2012 and 2016

\begin{tabular}{llll}
\hline & $\begin{array}{l}\text { Fish Hole Creek } \\
\text { (Babbage River) }\end{array}$ & $\begin{array}{l}\text { Fish Creek } \\
\text { (Rat River) }\end{array}$ & $\begin{array}{l}\text { Fish Creek (Ivvavik } \\
\text { National Park) }\end{array}$ \\
\hline Fork length (mm) & 360 & 220 & 269 \\
Round weight (g) & 437 & 99 & 237 \\
Age (years) & 4 & 5 & 6 \\
Fecundity & 1,389 & 657 & 729 \\
Mean egg diameter (mm) ( \pm SD) & $4.1(0.12)$ & $3.5(0.15)$ & $4.2(0.21)$ \\
Gonadosomatic index $(\%)$ & 17.4 & 16.7 & 13.2 \\
Date of capture & Sept. 21, 2012 & Sept. 27, 2014 & Sept. 24, 2016 \\
Location of capture & N 68.61114 W 138.72994 & N 67.90398 W 136.51666 & N 69.46244 W 140.24099 \\
\hline
\end{tabular}

The two resident females observed in the Canning River, Alaska between 1972 and 1973 measured 184 mm (age 6 years) and $240 \mathrm{~mm}$ (age 10 years; egg diameter $3.6 \mathrm{~mm}$ ) (Craig, 1977, p. 69)

removed for age estimation, their body cavity was opened to diagnose sex and reproductive condition, and gonads were weighed $( \pm 0.1 \mathrm{~g})$. One of each pair of otoliths was thin-sectioned for age estimation according to methods described by Gallagher et al. (2016). For the Fish Hole Creek sample, 21 gill rakers counted from the left gill arch was consistent with the value for resident males in the same system. The meristic character was useful to differentiate resident and isolated specimens in the Babbage River watershed that tend to have 20 gill rakers (Bain, 1974). Among years, the number of anadromous female current-year spawners measured during seining (large majority were live-sampled) was 1659 in Fish Hole Creek, 936 in Fish Creek (Rat R.), and 209 in Fish Creek (INP).

Otoliths of anadromous females from the Babbage River and Rat River populations were collected from subsistence harvest monitoring programmes on the Beaufort Sea coast (i.e., Shingle Point via genetic mixed-stock analysis; see Gallagher et al., 2018b), and the Mackenzie Delta and Rat River (see Harwood et al., 2009), respectively. Ovaries of anadromous current-year spawners from Fish Hole Creek were collected during seining in autumn 2014 and 2017. Ovaries from Fish Creek (Rat R.) females were collected from the spawning area in 2011 and the subsistence monitoring programme in 2015 and 2017. Otoliths and ovaries of anadromous females from Fish
Creek (INP) were collected during seining in autumn 2016 and 2017.

Given the low sample size of purported resident females, their individual percentiles of length (ranked highest to lowest) were used to determine where they fell in relation to sizes of resident males and anadromous spawning females. In addition, the same comparisons were made with boxplots using the median to inform how sizes compared among life histories for each river system.

Otolith laser ablation

Otolith $\mathrm{Sr}$ of the three purported resident females was compared to anadromous and resident male life histories to determine if they remained in freshwater throughout life. From each of the three locations, ten otoliths from anadromous and ten otoliths from resident male Dolly Varden were examined for comparison.

All thin-sectioned otoliths selected for laser ablation were embedded in acrylic rings, polished, cleaned, and photographed. Laser ablation inductively coupled plasma mass spectrometry (LA-ICP-MS) analysis (LUV 213 laser and Thermo Finnigan Element 2 ICP-MS) was conducted at the Department of Geological Sciences at the University of Manitoba. The ablation path was selected to perpendicularly cross annuli from the core (primordium) to the outer 
edge of the dorsal lobe of the otolith to obtain annual ${ }^{86} \mathrm{Sr}$ and Calcium $\left({ }^{43} \mathrm{Ca}\right)$ patterns throughout the life of the fish. The beam width was $30 \mu \mathrm{m}$ and moved at a speed of $2 \mu \mathrm{m} \mathrm{s}^{-1}$ with a repetition rate of $20 \mathrm{~Hz}$. A NIST 610 glass standard was analysed every hour, with 4 to 5 samples analysed per hour, while $\mathrm{Sr}$ was internally standardized against $\mathrm{Ca}$ for ablation yield (constant $\mathrm{Ca}$; in pure aragonite $40.02 \mathrm{wt} \%$ ) and quantified against a NIST 610 external standard reference. Iolite (v. 2.21) (Paton et al., 2011) was used to convert $\mathrm{Sr}$ counts per second to parts per million (ppm) by correcting to the Ca and NIST 610 standards. Sr profiles were overlaid on photographs of ablated otoliths to visualize variation in concentrations among annuli. Sr range (i.e., the difference between maximum and minimum $\mathrm{Sr}$ ) was plotted against maximum $\mathrm{Sr}$ in annuli $\geq 1$ year to identify nonmigratory and migratory individuals (Howland et al., 2009; Gallagher et al., 2018a).

Otolith back-calculations

Otolith back-calculations were conducted on the three purported resident females, anadromous females (71 from Fish Hole Creek, 77 from Fish Creek (Rat R.) and 17 from Fish Creek (INP)), and resident males (61 from Fish Hole Creek, 73 from Fish Creek (Rat R.) and 27 from Fish Creek (INP)) to compare early size-at-age prior to age-at-capture. Otolith sections were polished with lapping film and photographed using a digital camera attached to a dissecting microscope. ImageJ 1.44 (www.rsb.info. nih.gov/ij; National Institutes of Health) was used to measure distance from the nucleus to each annulus. Annuli were measured on a straight line $50^{\circ}$ from the nucleus to the outer edge of the ventral lobe. The biological intercept back-calculation model (Campana, 1990) was used to back-calculate size-at-age for residents:

$L_{\mathrm{i}}=L_{\mathrm{c}}+\frac{\left(O_{\mathrm{i}}-O_{\mathrm{c}}\right)\left(L_{\mathrm{c}}-L_{\mathrm{h}}\right)}{\left(O_{\mathrm{c}}-O_{\mathrm{h}}\right)}$,

where $L_{\mathrm{i}}$ is the back-calculated length at a given age, $L_{\mathrm{c}}$ is the fish length at capture, $L_{\mathrm{h}}$ is the fish length at hatch, $O_{\mathrm{i}}$ is the otolith size at a given age, $O_{\mathrm{c}}$ is the otolith size at capture, and $O_{\mathrm{h}}$ is the otolith size at hatch. $L_{\mathrm{h}}$ and $O_{\mathrm{h}}$ values were obtained from the literature (Blackett, 1968; Armstrong \& Morrow,
1980; Radtke et al., 1996). Due to a decoupling observed during first migration in Dolly Varden populations, a modified biological intercept model, the biological intercept breakpoint (Morrison et al. 2019), was used to back-calculate size-at-age for anadromous females:

$$
\begin{aligned}
& L_{\mathrm{i}}=L_{\mathrm{c}}+\frac{\left(L_{\mathrm{c}}-L_{\mathrm{j} 1}\right)\left(O_{\mathrm{i}}-O_{\mathrm{c}}\right)}{\left(O_{c}-O_{j}\right)} \quad \text { if } j \geq O^{\prime} j \\
& L_{\mathrm{j} 2}+\frac{\left(L_{\mathrm{j} 2}-L_{\mathrm{h}}\right)\left(O_{\mathrm{i}}-O_{\mathrm{j}}\right)}{\left(O_{\mathrm{j}}-O_{\mathrm{h}}\right)} \quad \text { if } j<O^{\prime} j
\end{aligned}
$$

where $L_{\mathrm{j} 1}$ is length directly after first migration, $L_{\mathrm{j} 2}$ is length directly before first migration, $O_{\mathrm{j}}$ is the estimated otolith size at first migration, and $O^{\prime} \mathrm{j}$ is the individual otolith size at first migration. First migration was determined from otolith $\mathrm{Sr}$ profiles. $L_{\mathrm{j} 1}, L_{\mathrm{j} 2}$, and $O_{\mathrm{j}}$ were estimated from population and sexspecific piecewise regressions for fish from Fish Hole Creek and Fish Creek (Rat R.), whereas a sex-specific piecewise regression from multiple Dolly Varden populations was used to obtain values for the Fish Creek (INP) population (see Morrison et al., 2019). Regressions and back-calculations were completed in R (R Core Team, 2017).

Fecundity, egg diameter and gonadosomatic index

Anadromous females spawning in the current-year were sampled from each of the populations to estimate fecundity, egg diameter, and gonadosomatic index (GSI) for comparison with the purported resident female from the same system. Fecundity and GSI were estimated from 10 fish from Fish Hole Creek (336-603 $\mathrm{mm}$ ) and egg diameter was estimated from 11 fish (one fish was partially spent and was not used for fecundity). Fecundity, egg diameter, and GSI were estimated for 24 fish from the Rat River (435-690 mm). Fecundity and GSI were estimated for 11 fish from Fish Creek (INP) (423-539 mm) while egg diameter was estimated for 14 fish (three fish were partially spent so were not used for fecundity). Ovaries were frozen and later thawed and preserved in a $10 \%$ formalin solution for counting eggs. Egg diameter was estimated from the mean of three measurements of 10 randomly selected eggs aligned on a ruler. GSI (\%) was calculated as: (gonad weight/total weight $) \times 100$. 
For each river, fecundity and length of anadromous fishes were $\log _{10}$ transformed. Linear regression was used to predict fecundity ( $\pm 95 \%$ confidence intervals) at a particular length. The log transformed fecundity and length of each purported resident female was compared to $95 \%$ confidence intervals of each population regression. Egg diameter was treated similarly, but was not $\log _{10}$ transformed. GSI was not significantly correlated with fork length of anadromous current-year spawners, therefore GSI of purported resident females was compared to boxplots of anadromous females.

\section{Results}

Phenotype

Phenotypically, the three resident females had similar colouration that was characterized as dark brown throughout the body, with a light yellowish ventral surface (Fig. 2A-D). All had small red spots along their sides between the head and tail, and white leading edges on pectoral, pelvic, and anal fins. Rectangular parr marks on females from Fish Creek (Rat R. and INP) were not as visible on the female from Fish Hole Creek (Fig. 2A). Phenotypically, resident females were similar to resident males in spawning condition (Fig. 2E) (Armstrong \& Morrow, 1980; COSEWIC, 2010) and did not have spawning colouration like anadromous females that had a dark back and dark olive sides with pink spots encircled by bluish halos between the head and tail, and a lightly violet ventral surface (Fig. 2F).

\section{Otolith strontium}

Plots of the $\mathrm{Sr}$ range and maximum $\mathrm{Sr}$ concentration revealed two distinct groups belonging to known migratory and resident life histories in each river (Fig. 3). Anadromous fishes had a high $\mathrm{Sr}$ range (1770-3640 ppm) and a high maximum $\mathrm{Sr}$ (2150-3890 ppm), while residents had a low $\mathrm{Sr}$ range (250-920 ppm) and low maximum $\mathrm{Sr}$ (460-1290 ppm). The $\mathrm{Sr}$ of purported resident females overlapped those of resident males, which confirms the three were life-long resident females (Fig. 3). The amplitude of strontium concentration did not change dramatically among annuli of resident
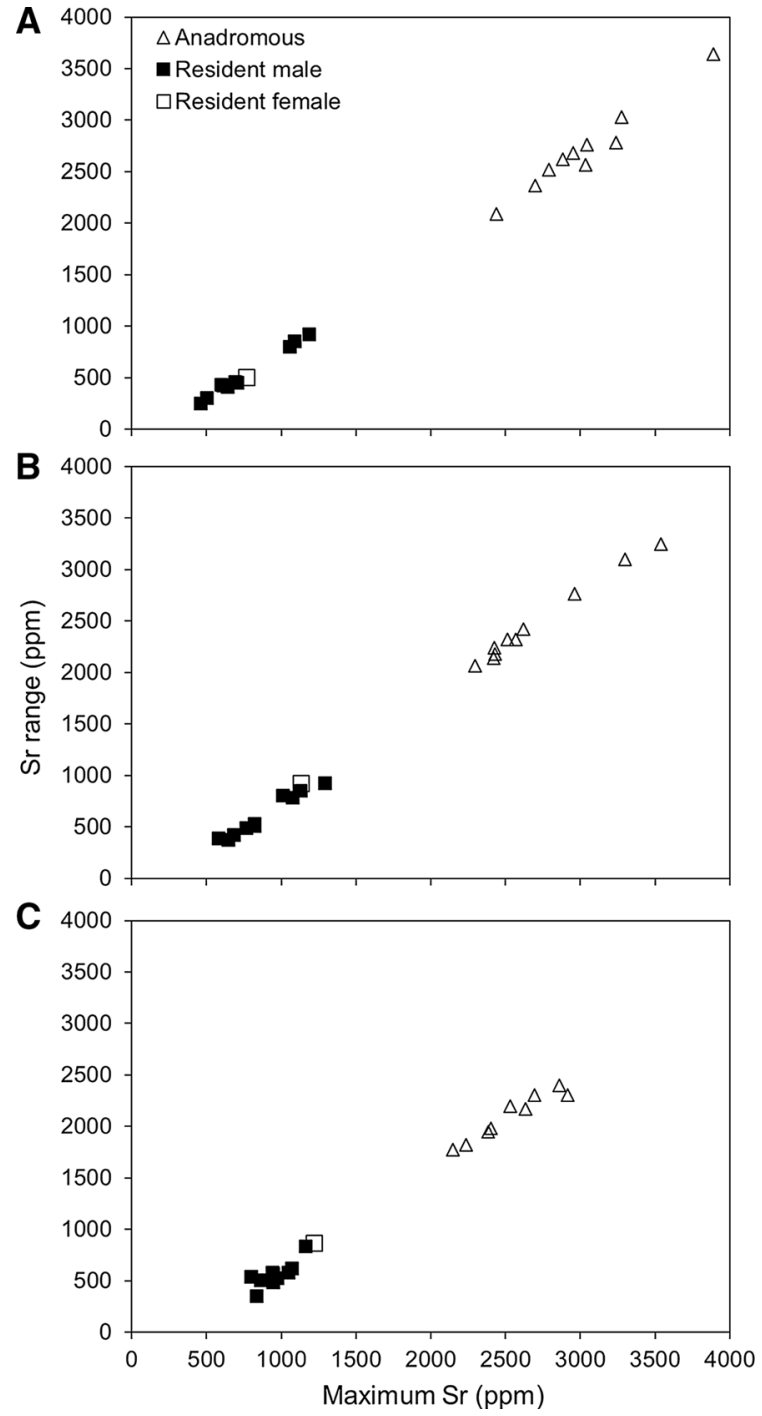

Fig. 3 Otolith strontium (Sr) range (difference in Sr concentration between the maximum and minimum values) plotted against maximum $\mathrm{Sr}$ of anadromous, resident male, and resident female Dolly Varden from A Fish Hole Creek (Babbage River population), B Fish Creek (Rat River population), and C Fish Creek (in Ivvavik National Park)

females as in anadromous females after they migrate to sea (see Gallagher et al., 2018a).

Catch composition

Resident females were a small fraction of the total number of residents sampled at spawning locations in autumn. Residents females accounted for $0.81 \%$ 


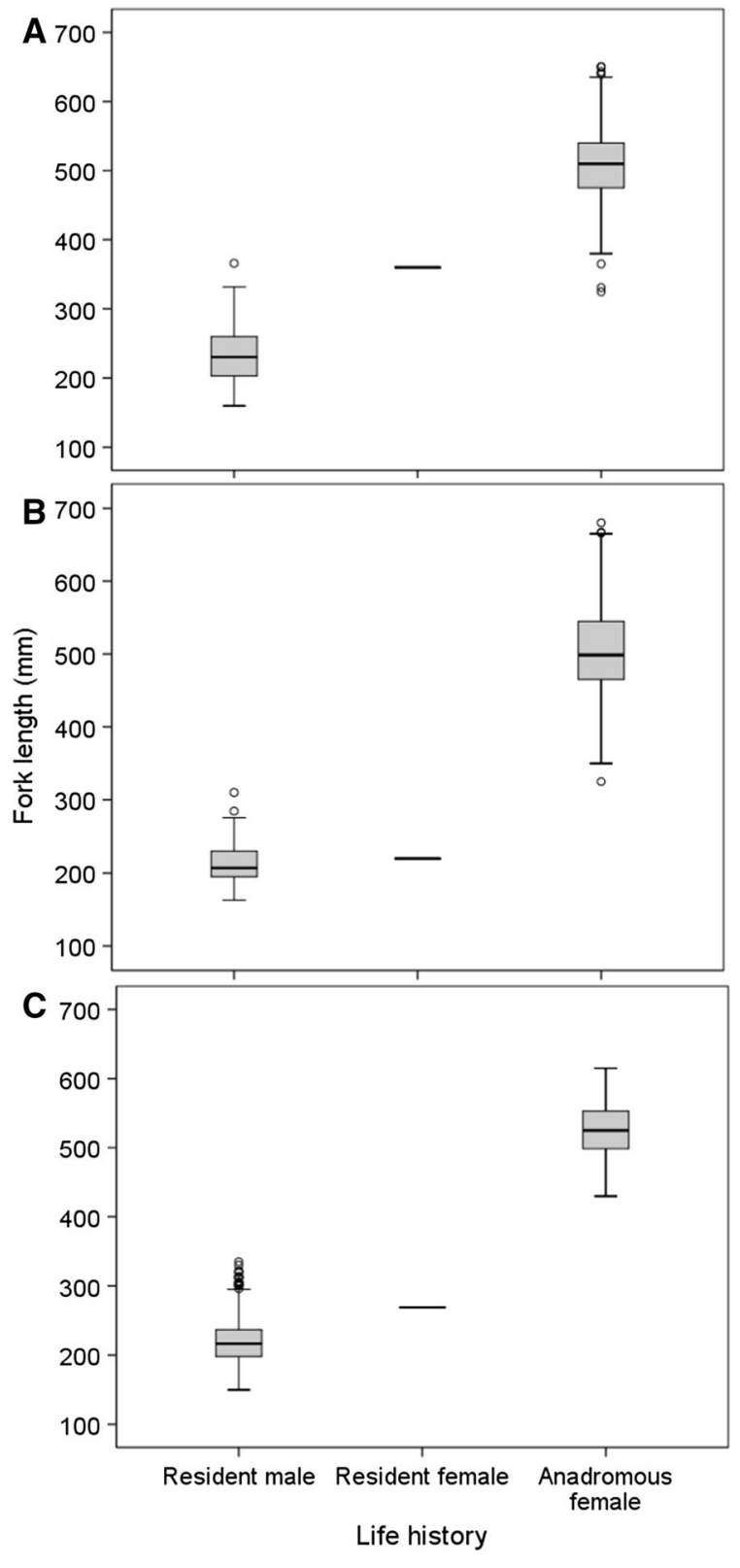

Fig. 4 Fork length of current-year spawning resident female Dolly Varden between boxplots (median, quartiles and outliers (open circle; values $\geq 1.5 \times$ inter-quartile range)) of currentyear spawning resident males and anadromous females in $\mathbf{A}$ Fish Hole Creek (Babbage River population), B Fish Creek (Rat River population), and C Fish Creek (in Ivvavik National Park) captured while seining in mid- to late September at spawning locations

of total resident catches in Fish Hole Creek, 0.39\% in Fish Creek (Rat R.), and $0.21 \%$ in Fish Creek (INP).
Size-at-Capture and Size-at-Age

The resident female from Fish Hole Creek was the largest $(360 \mathrm{~mm})$, followed by Fish Creek (INP) (269 mm) and Fish Creek (Rat R.) $(220 \mathrm{~mm})$ females (Table 1). Length of the female from Fish Hole Creek was among the largest residents from this system captured between 2010 and 2017 (99th percentile), with only one 366-mm male being longer (Fig. 4A). Both of these fish were larger than other residents (median $=235 \mathrm{~mm}$; range $160-332 \mathrm{~mm}$; Fig. 4A). The resident female overlapped in size with small sexually mature anadromous females (0.1th percentile; range $325-650 \mathrm{~mm}$; median $=509 \mathrm{~mm}$; Fig. 4A). The resident female from Fish Creek (Rat R.) was slightly larger (67th percentile) than resident males $($ median $=207 \mathrm{~mm}$; range 163-310 mm), but much smaller than anadromous spawning females $($ median $=499 \mathrm{~mm}$; range $325-680 \mathrm{~mm}$; Fig. 4B) . The resident female from Fish Creek (INP) was among the largest residents (90th percentile; range 150-335 mm; median $=217 \mathrm{~mm}$ ), but was smaller than spawning anadromous females (median $=525 \mathrm{~mm}$; range 430-615 mm; Fig. 4C).

Resident females were generally longer at age than other Dolly Varden in each stream. The resident female from Fish Hole Creek was longer at age than pre-smolt anadromous females starting at age 2 , but overlapped with several large pre-smolt anadromous females at age 1 (Fig. 5A). Similarly, the resident female from Fish Hole Creek was longer at age than all but one resident male starting at age 2 . The resident female from Fish Creek (Rat R.) was within length ranges of both pre-smolt anadromous females and resident males, but was among the larger backcalculated sizes-at-age, particularly when compared to pre-smolt anadromous females (Fig. 5B). The resident female from Fish Creek (INP) was similar to the $75^{\text {th }}$ percentile of length at age for pre-smolt anadromous females and the 90th percentile for resident males (Fig. 5C).

\section{Reproductive characteristics}

Fecundity of resident females fell within $95 \%$ confidence intervals of the relationship between length and egg count of anadromous Dolly Varden (Fig. 6). The resident female from Fish Hole Creek was the only fish with greater fecundity (1185 eggs) at length (336 mm) 

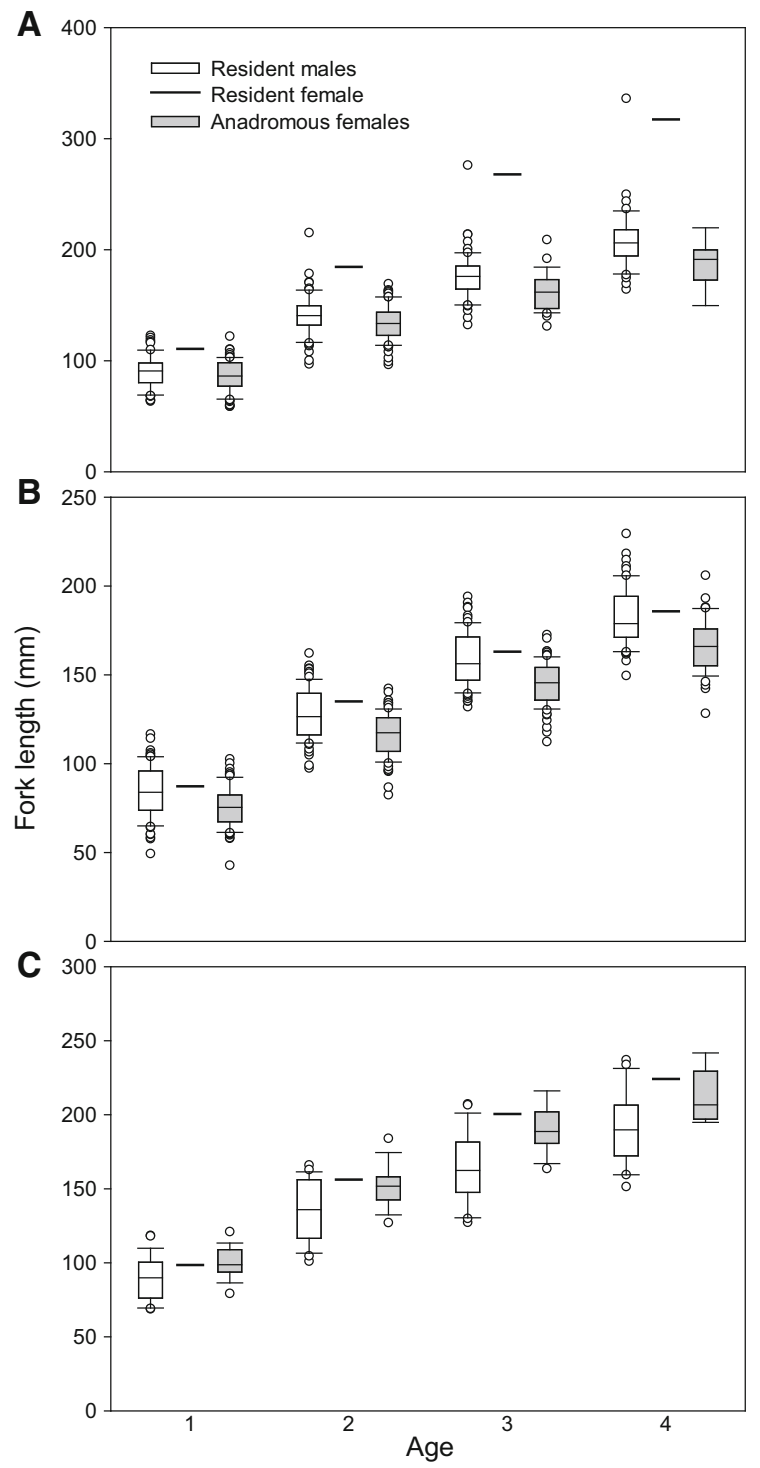

Fig. 5 Otolith back-calculated size-at-age of resident female Dolly Varden between boxplots [median, quartiles and outliers (open circle; values $\geq 1.5 \times$ inter-quartile range)] of backcalculated resident males and anadromous females (prior to first ocean migration) in A Fish Hole Creek (Babbage River population), B Fish Creek (Rat River population), and C Fish Creek (in Ivvavik National Park)

than the smallest anadromous fish of the same length (Fig. 6A). Immature oocytes found in the Fish Creek (Rat R.) resident female (Fig. 2C) would presumably be used for reproducing in the following year (not used for fecundity or GSI calculations).

Mean egg diameter of residents was similar to small-sized ( $\sim 400 \mathrm{~mm}$ ) anadromous Dolly Varden
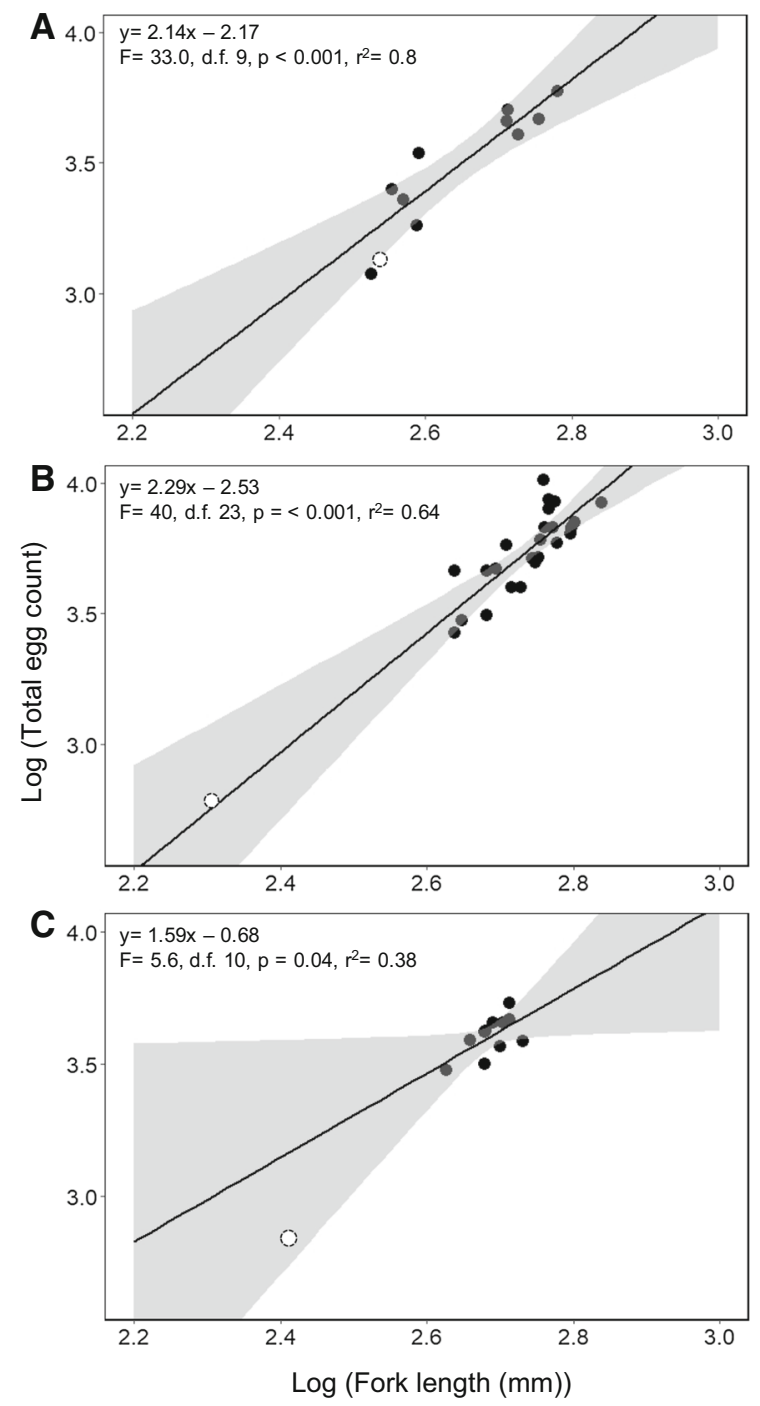

Fig. 6 Linear regression of $\log _{10}$-transformed total egg count (fecundity) and fork length (closed circles) with $95 \%$ confidence intervals (grey shaded area) of anadromous current-year spawning Dolly Varden from A Fish Hole Creek (Babbage River population), B Fish Creek (Rat River population), and C Fish Creek (in Ivvavik National Park). Resident datum (open circle) was overlaid on the linear regression model of anadromous fish. Regression equation, $F$ statistic, degrees of freedom (d.f.), $P$ value, and coefficient of determination $\left(r^{2}\right)$ are included in each panel

in Fish Hole Creek and Fish Creek (INP) ( $4.2 \mathrm{~mm})$, but larger than small-sized anadromous Dolly Varden in Fish Creek (Rat R.) (3.5 mm) (Table 1; Fig. 7). GSI of resident females varied among streams. The resident female GSI (17.4\%) overlapped with anadromous females $($ median $=22 \%)$ in Fish Hole Creek, 
was higher $(16.7 \%)$ than anadromous females (median $=10 \%$ ) in Fish Creek (Rat R.), and was lower $(13.2 \%)$ than anadromous females $($ median $=21 \%)$ in Fish Creek (INP) (Fig. 8).
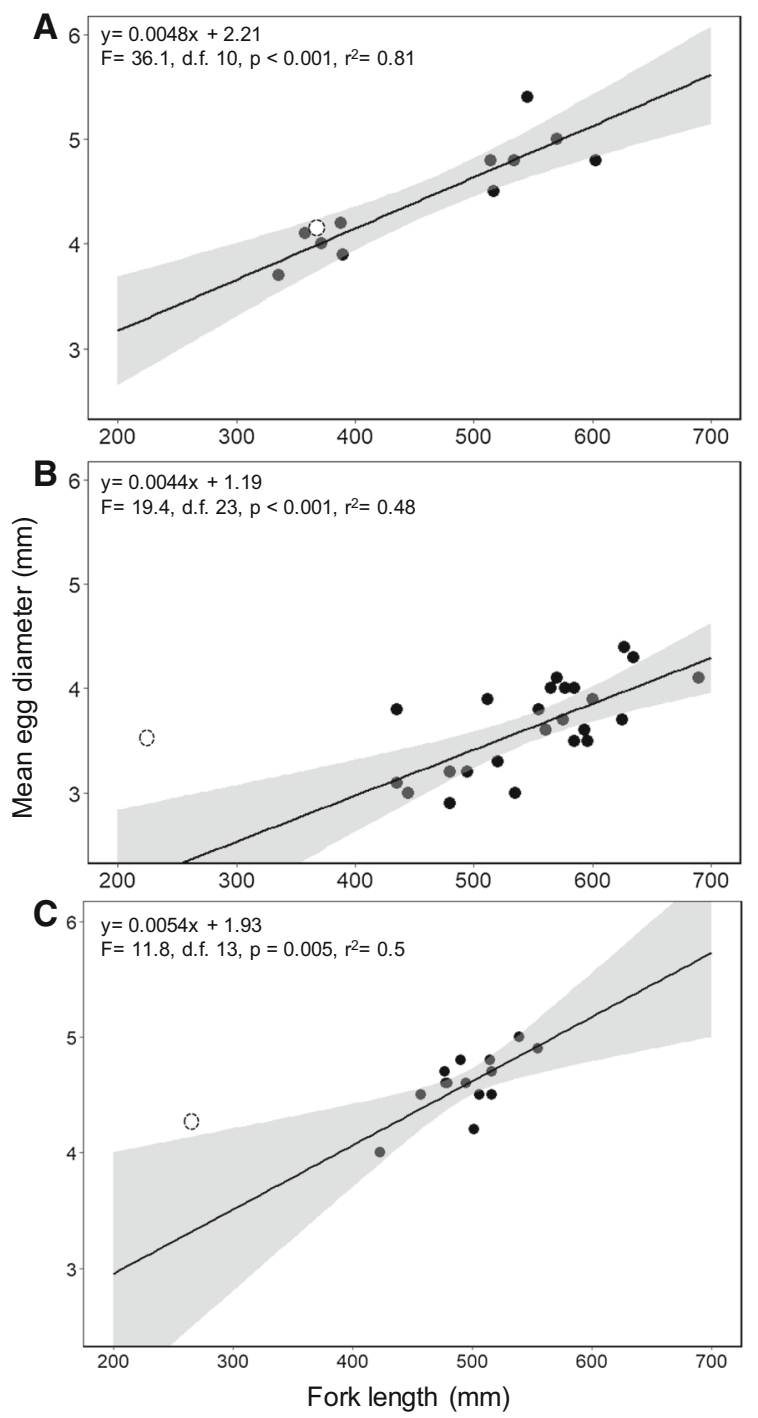

Fig. 7 Linear regression of egg diameter and fork length (closed circles) with 95\% confidence intervals (grey-shaded area) of current-year spawning anadromous Dolly Varden from A Fish Hole Creek (Babbage River population), B Fish Creek (Rat River population), and C Fish Creek (in Ivvavik National Park). Resident datum (open circle) was overlaid on the linear regression model of anadromous fish. Regression equation, $F$ statistic, degrees of freedom (d.f.), $P$-value, and coefficient of determination $\left(r^{2}\right)$ are included in each panel

\section{Discussion}

We are the first to use a combination of visual assessment of phenotype and otolith $\mathrm{Sr}$ analysis to confirm that female northern Dolly Varden in North America can adopt a resident life history strategy in populations that exhibit partial migration. Although resident females are rare $(<1 \%$ of total residents sampled), conditional mating tactics of Dolly Varden can be expressed by both sexes in multiple populations. Our results also confirm the presence of resident females in river systems further east than previously observed (i.e., Canning River and Fish Creek (INP); Fig. 1) and provides new records for Fish Hole Creek and Fish Creek (Rat R.). Furthermore, a resident female life history is not restricted to populations experiencing long (i.e., Fish Creek (Rat R.)) or short (i.e., Fish Creek (INP)) migration distances, therefore distance may not have a strong effect on costs or benefits assessed by juvenile females during selection of migratory tactic. Biological characteristics of the three resident females tended towards larger size-atage than resident males and pre-smolt anadromous females, and had similar fecundity predicted for length and egg size compared to small anadromous females. Although fork length of resident females was not consistently larger or smaller than resident males, two resident females were among the largest sized residents in their river system. GSI of resident females was not consistently higher or lower than anadromous females. Although sample size was low, large juvenile females could adopt a resident life history and obtain reproductive benefits similar to small anadromous females (e.g., <350 mm based on Fish Hole Creek sample) without having to endure the mortality risk associated with ocean migration and feeding.

Our results suggesting resident female size-at-age was greater than or similar to large pre-smolt anadromous individuals is similar to the single resident female Dolly Varden examined by Gruzdeva et al. (2017) and to observations of resident male Dolly Varden (Gruzdeva et al., 2017; Morrison, 2017). Furthermore, our results are consistent with findings in other salmonines (Rikardsen \& Elliott, 2000; AubinHorth \& Dodson, 2004; Morita et al., 2014; Rosenfeld et al., 2015). Few studies have specifically examined the influence of growth on resident females, although resident female brown trout (Salmo trutta (L.)) weighed less, were in poorer condition, and grew 
Fig. 8 Gonadosomatic index (GSI; \%) of currentyear spawning resident female Dolly Varden and boxplots of current-year spawning anadromous females in Fish Hole Creek (Babbage River population), Fish Creek (Rat River population), and Fish Creek (in Ivvavik National Park, INP)

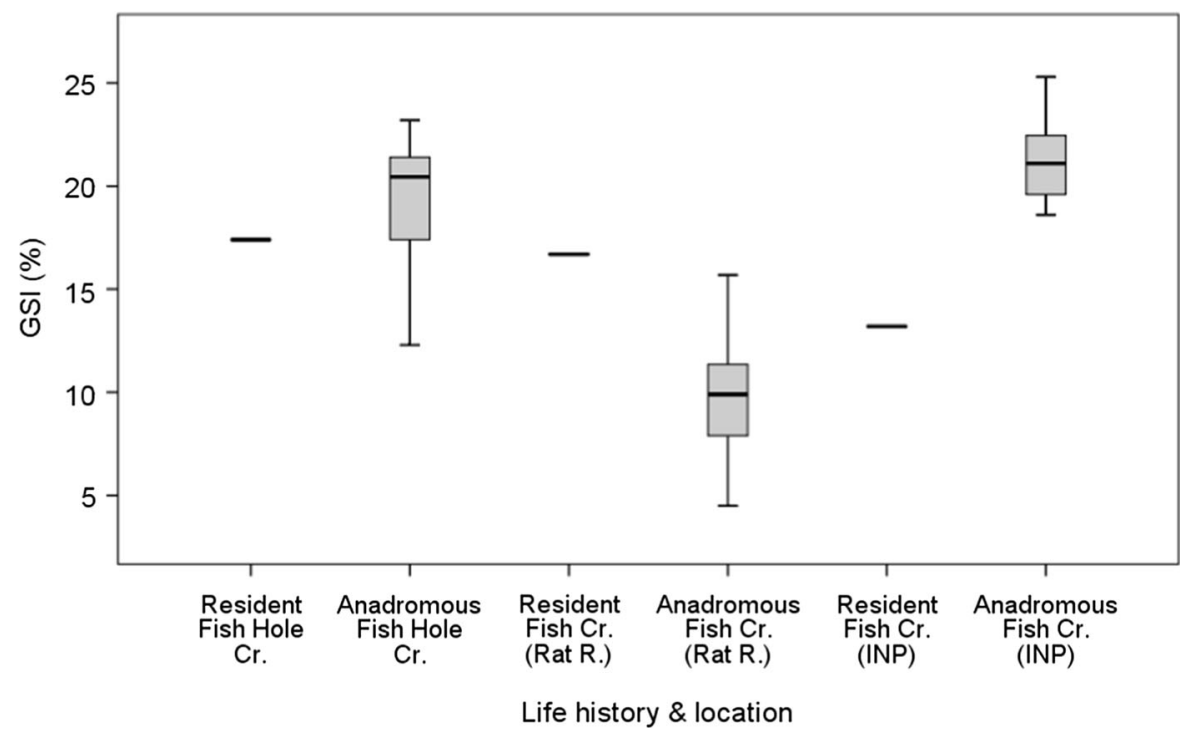

slower than resident males in one experiment that tested for differences in growth-related variables between both sexes that adopted either a resident or anadromous life history at different levels of food availability (Wysujack et al., 2009). The heaviest female brown trout tended to become anadromous, although Fulton's condition factor was slightly higher for resident than anadromous females (Wysujack et al., 2009), which contrasts with our size-at-age results showing resident females tended to be larger than anadromous females. Nonetheless, we hypothesize that larger size-at-age may have been accompanied by higher condition that presumably allowed resident females to capitalize on an energetic state in a crucial time window (Wysujack et al., 2009) to adopt a resident life history. Another study examining size-atage between sexes of resident brown trout only found a difference between males and females (i.e., was larger) within a single age class (Jonsson, 1985).

The fecundity of resident females falling within the 95\% confidence intervals of anadromous females is consistent with the observation in Arctic charr (Loewen et al., 2010). Similarly, egg diameter of resident females was equal to small-sized anadromous Arctic charr (Loewen et al., 2010) and brown trout (Jonsson, 1985). These observations collectively inform some of the trade-offs involved in the 'decision' by a female to adopt a resident or anadromous life history in partially migratory populations. Our results indicate the investment by resident females into reproduction may be similar to small-sized anadromous females. For Dolly Varden, benefiting from a resident life history presumably requires maximizing fecundity, which is a possible reason why females tended to be among the largest residents. Given the positive correlation between female length and egg size that presumably resulted in greater offspring fitness (reviewed by Einum et al., 2004), resident Dolly Varden appear to invest in juvenile survival (i.e., egg size) to a similar extent as small-sized anadromous counterparts. However, without knowing characteristics of nest construction by resident female Dolly Varden, we speculate that one of the costs of adopting a resident life history is that egg survival may not be as high if females are limited in the depth of their nest construction to protect fertilized eggs, given the positive relationship between female size and nest depth (van den Berghe \& Gross, 1984). If resident and anadromous females preferred different spawning substrate characteristics, it is possible we may have underestimated the relative abundance of resident females given that we were targeting anadromous females. Interestingly, the smaller egg size of the Rat River population may have permitted the resident female to reproduce at a relatively smaller size compared to the other populations.

Another trade-off is the presumably reduced availability of carotenoid pigments to resident females compared to anadromous females who obtain these while feeding in the marine environment (Craig \& 
Foote, 2001). Maternal provisioning of carotenoids to eggs imparts advantages for egg size and early life survival in salmonids (Tyndale et al., 2008). Differences in the amount of carotenoids deposited into eggs between resident and anadromous females may be reflected by distinct egg colouration between both life histories where a darker colouration could be expected for the more carotenoid-rich eggs (i.e., presumably from anadromous individuals) (Lehnert et al., 2018). The colour of resident Dolly Varden ovaries appeared different among the three samples based on visual assessment (see Fig. 2) suggesting differences in availability and or accumulation of dietary carotenoids among populations. It is noted that resident female ovaries did not appear to differ substantially from anadromous counterparts based on visual assessment, particularly for the Fish Creek (Rat R.) sample (C. Gallagher pers. obs.). Research is required to determine how maternal provisioning of carotenoids in Dolly Varden influence egg size and offspring fitness to inform potential trade-offs.

While reproductive investment (fecundity and egg diameter) appears similar (after accounting for length) between resident and small-sized anadromous females, we do not know the extent of reproductive success of resident females in the populations we examined. In brook charr ( $S$. fontinalis (Mitchell)), anadromous females had higher reproductive success than resident females, although the number of offspring produced between resident and small anadromous females $(<350 \mathrm{~mm})$ overlapped (Thériault et al., 2007). Reproductive success in iteroparous fishes is also associated with spawning frequency. Although the spawning frequency of resident female northern Dolly Varden is unknown, $48.8 \%$ and $92 \%$ of anadromous females from the Rat River and Babbage River populations, respectively, spawn in consecutiveyears based on results from mark-recapture studies (Gallagher et al., 2018a, b) (note, data currently not available for Fish Creek (INP)). It is noted that the immature oocytes in the ovary of the Fish Creek (Rat R.) resident (see Fig. 2C) suggests reproduction occurs in consecutive-years as the immature oocytes $(1.0 \pm 0.1 \mathrm{~mm}$ in diameter) could become mature in the following year (see Gruzdeva et al., 2017) assuming energetic thresholds are met for oocyte maturation (Rideout et al., 2005). Assuming the spawning frequency (among other reproductive characteristics) of resident females is optimized to provide fitness that is similar to or better than small anadromous females, research is needed to determine if spawning frequency between the female resident and anadromous life histories are similar and whether the spawning frequency of residents varies among populations as it does for anadromous females.

Identifying a resident female in Fish Hole Creek raises a concern that the fish may have originated from the isolated population in the Babbage River (see Fig. 1), as mentioned by Craig (1977) about specimens observed in the Canning River, which also has an isolated population in the watershed. Although anadromous and resident Dolly Varden in Fish Hole Creek appears to be reproductively isolated from those found above the falls of the Babbage River, a small degree of gene flow is evident in the downstream direction. Several isolated individuals downstream of the waterfalls were identified within the Babbage River (Harris et al., 2015) using Bayesian clustering analysis (STRUCTURE, Pritchard et al., 2000). Further, seven small-sized mature females $(<241 \mathrm{~mm})$ found in the Babbage River in a deep pool immediately below the falls were thought to have originated from the isolated population above the falls based on meristic characters (Bain, 1974). The likelihood that a resident female from Fish Hole Creek descended the waterfalls of the Babbage River and found its way to the upper reach of Fish Hole Creek is presumed low, given the distinctive biological characteristics of isolated females. Most isolates in the Babbage River were $<294 \mathrm{~mm}$ in length $(99.4 \%$ of 502 sampled, with only $0.6 \%$ measuring $355-547 \mathrm{~mm}$ ), with fecundities ranging 134-649 eggs, and egg diameters of $2.9 \mathrm{~mm} \pm 0.44$ at the end of September (similar time of the year to our study; Bain, 1974). Had the resident female originated from an isolated population, we would have, at the very least, expected lower fecundity, smaller egg diameter, and lower gill-raker count.

Research on resident females among partially migratory populations, particularly where they are rare like northern Dolly Varden in North America, can be relevant for monitoring effects of climate change on freshwater productivity. Increasing freshwater productivity is predicted to decrease the prevalence of anadromy (Finstad \& Hein, 2012). The life-long resident females in Dolly Varden populations inhabiting the Chignik Lake watershed were sympatric with previously anadromous individuals that had ceased to undertake annual migrations to the sea presumably 
due to foraging opportunities subsidized by the predictable annual supply of eggs and carcasses of spawning Pacific salmon (Bond et al., 2015). New records of adult vagrant Pacific salmon captured in sympatry with spawning Dolly Varden (anadromous and residents) in Fish Hole Creek $(n=1)$ and Fish Creek (INP) $(n=2)$ (C. Gallagher pers. obs.) are indicative of salmon accessing and potentially colonizing these Arctic river systems in response to the warming of Arctic marine habitats (see Dunmall et al., 2013, 2016). We hypothesize that if Pacific salmon become more frequent in these river systems, they may provide enough allochthonous sources of energy to increase the prevalence and abundance of life-long resident females in Dolly Varden populations that do not currently co-exist with salmon. To that end, more sampling is required to locate other populations exhibiting the resident female life history tactic. Establishing a benchmark of relative abundance of resident females could be a useful measure to monitor and assess the potential effects of climate change on life history tactics of partially migratory salmonid populations.

Documenting locations, estimating the relative abundance, and describing the size-at-age and reproductive characteristics of resident females is useful to improve our understanding of life history diversity and bet-hedging strategies used by facultatively anadromous Dolly Varden. Our results demonstrate that conditional mating tactics of northern Dolly Varden can be expressed by both sexes in multiple populations. The low number of resident females we encountered underscores the need for more research to elucidate physiological and ecological factors influencing a juvenile female Dolly Varden's 'decision' regarding life history selection and to inform the interpretation that fast growth of juvenile females contributes, among other complex variables (see Wysujack et al., 2009), to the expression of alternative reproductive tactics.

Acknowledgements Funding was provided by Inuvialuit Final Agreement implementation funds (Fisheries Joint Management Committee), Fisheries and Oceans Canada Northern Operations (Larry Dow), Fisheries and Oceans Canada Species at Risk, and the Gwich'in Renewable Resources Board (Wildlife Studies Fund). In-kind support was provided by Parks Canada Agency (David Tavares and Nelson Perry) and the Polar Continental Shelf Program. We thank Tracey Loewen (Fisheries and Oceans Canada) for sharing otolith strontium data useful for some of the growth analyses.
We are thankful for the otolith expertise provided by Rick Wastle (Fisheries and Oceans Canada) and the Zhe Song (University of Manitoba Department of Geology), and the support provided by the Ehditaat Renewable Resources Council, Aklavik Hunters and Trappers Committee, West Side Working Group, and Rat River Working Group. Adriana Rivas Ruiz (Fisheries and Oceans Canada) produced the map illustrated in Fig. 1.

Open Access This article is distributed under the terms of the Creative Commons Attribution 4.0 International License (http:// creativecommons.org/licenses/by/4.0/), which permits unrestricted use, distribution, and reproduction in any medium, provided you give appropriate credit to the original author(s) and the source, provide a link to the Creative Commons license, and indicate if changes were made.

\section{References}

Armstrong, R. H. \& J. E. Morrow, 1980. The Dolly Varden charr, Salvelinus malma. In Balon, E. K. (ed.), Charrs: salmonid fishes of the genus Salvelinus. Dr. W. Junk Publishers, The Hague: 99-140.

Aubin-Horth, N. \& J. J. Dodson, 2004. Influence of individual body size and variable thresholds on the incidence of a sneaker male reproductive tactic in Atlantic salmon. Evolution 58: 136-144.

Bain, L. H., 1974. Life histories and systematics of arctic char (Salvelinus alpinus, L.) in the Babbage River system, Yukon Territory. In McCart, P. J. (ed), Life histories of three species of freshwater fishes in the Beaufort Sea drainages, Yukon Territory. Arctic Gas Biological Report Series 18.

Berejikian, B. A., D. M. Van Doornik, R. C. Endicott, T. L. Hoffnagle, E. P. Tezak, M. E. Moore \& J. Atkins, 2010. Mating success of alternative male phenotypes and evidence for frequency-dependent selection in Chinook salmon, Oncorhynchus tshawytscha. Canadian Journal of Fisheries and Aquatic Sciences 67: 1933-1941.

Blackett, R. F., 1968. Spawning behavior, fecundity, and early life history of anadromous Dolly Varden, Salvelinus malma (Walbaum) in Southeastern Alaska. Alaska Department of Fish and Game Research Report 6.

Bond, M. H., J. A. Miller \& T. P. Quinn, 2015. Beyond dichotomous life histories in partially migrating populations: cessation of anadromy in a long-lived fish. Ecology 96: 1899-1910.

Campana, S. E., 1990. How reliable are growth back-calculations based on otoliths? Canadian Journal of Fisheries and Aquatic Sciences 47: 2219-2227.

Chapman, B. B., C. Brönmark, J.-Å. Nilsson \& L.-A. Hansson, 2011. The ecology and evolution of partial migration. Oikos 120: 1764-1775.

Clutton-Brock, T. H., 1988. Reproductive success. In CluttonBrock, T. H. (ed.), Reproductive success: studies of individual variation in contrasting breeding systems. University of Chicago Press, Chicago: 472-485. 
COSEWIC, 2010. COSEWIC assessment and status report on the Dolly Varden Salvelinus malma malma (Western Arctic populations) in Canada. Committee on the Status of Endangered Wildlife in Canada, Ottawa.

Craig, P. C., 1977. Ecological studies of anadromous and resident populations of Arctic char in the Canning River drainage and adjacent coastal waters of the Beaufort Sea, Alaska. In McCart, P. (ed.), Fisheries investigations along the North Slope and Beaufort Sea coast with emphasis on Arctic char. Arctic Gas Biological Report Series 41.

Craig, P. C., 1978. Movements of stream-resident and anadromous Arctic char (Salvelinus alpinus) in a perennial spring on the Canning River, Alaska. Journal of the Fisheries Research Board of Canada 35: 48-52.

Craig, P. C. \& P. McCart, 1976. Fish use of nearshore coastal waters in the western arctic: emphasis on anadromous species. In Wood, D. W. \& D. C. Burrell (eds), Assessment of the arctic marine environment. Occasional publication number 4, Institute of Marine Science, University of Alaska Fairbanks.

Craig, J. K. \& C. J. Foote, 2001. Countergradient variation and secondary sexual color: phenotypic convergence promotes genetic divergence in carotenoid use between sympatric anadromous and nonanadromous morphs of sockeye salmon (Oncorhynchus nerka). Evolution 55: 380-391.

DFO, 2017. Assessment of Dolly Varden from the Rat River, Northwest Territories 2009-2014. DFO Canadian Science Advice Secretariat Science Advisory Report 2016/058.

Dunmall, K. M., J. D. Reist, E. C. Carmack, J. A. Babaluk, M. P. Heide-Jørgensen \& M. F. Docker, 2013. Pacific salmon in the Arctic: harbingers of recent great changes. In Mueter, F. J., D. M. S. Dickson, H. P. Huntington, J. R. Irvine, E. A. Logerwell, S. A. MacLean, L. T. Quakenbush \& C. Rosa (eds), Responses of Arctic marine ecosystems to climate change. Alaska Sea Grant, University of Alaska Fairbanks, Alaska: 141-163.

Dunmall, K. M., N. J. Mochnacz, C. E. Zimmerman, C. Lean \& J. D. Reist, 2016. Using thermal limits to assess establishment of fish dispersing to high-latitude and high-elevation watersheds. Canadian Journal of Fisheries and Aquatic Sciences 73: 1750-1758.

Einum, S., M. T. Kinnison \& A. P. Hendry, 2004. Evolution of egg size and number. In Hendry, A. P. \& S. C. Stearns (eds), Evolution illuminated: salmon and their relatives. Oxford University Press, New York: 126-153.

Finstad, A. G. \& C. L. Hein, 2012. Migrate or stay: terrestrial primary productivity and climate drive anadromy in Arctic char. Global Change Biology 18: 2487-2497.

Forseth, T., T. F. Naesje, B. Jonsson \& K. Hårsaker, 1999. Juvenile migration in brown trout: a consequence of energetic state. Journal of Animal Ecology 68: 783-793.

Fleming, I. A., 1996. Reproductive strategies of Atlantic salmon: ecology and evolution. Reviews in Fish Biology and Fisheries 6: 379-416.

Fleming, I. A. \& J. D. Reynolds, 2004. Salmonid breeding systems. In Hendry, A. P. \& S. C. Stearns (eds), Evolution illuminated: salmon and their relatives. Oxford University Press, New York: 264-294.

Gallagher, C. P., M. -J. Roux, K. L. Howland \& R. F. Tallman, 2012. Synthesis of biological and harvest information used to assess populations of northern form Dolly Varden
(Salvelinus malma malma) in Canada. Part III: Comparison among populations. DFO Canadian Science Advisory Secretariat Research Document 2011/128.

Gallagher, C. P., K. L. Howland \& R. J. Wastle, 2016. A comparison of different structures and methods for estimating age of northern-form Dolly Varden Salvelinus malma malma from the Canadian Arctic. Polar Biology 39: 1257-1265.

Gallagher, C. P., K. L. Howland, S. J. Sandstrom \& N. M. Halden, 2018a. Migration tactics affect spawning frequency in an iteroparous salmonid (Salvelinus malma) from the Arctic. PLoS ONE 13(12): e0210202.

Gallagher, C. P., K. L. Howland, R. Bajno, S. J. Sandstrom \& J. D. Reist, 2018b. Population abundance, biological characteristics, and contribution to coastal mixed-stock fisheries of Dolly Varden (Salvelinus malma malma) from the Babbage River: 2010-2014. DFO Canadian Science Advisory Secretariat Research Document 2018/029.

Glova, G. \& P. J. McCart, 1974. Life history of Arctic char (Salvelinus alpinus) in the Firth River, Yukon Territory. In McCart, P. (ed), Life histories of anadromous and freshwater fish in the western Arctic. Arctic Gas Biological Report Series 20.

Gross, M. R., 1996. Alternative reproductive strategies and tactics: diversity within sexes. Trends in Ecology and Evolution 11: 92-98.

Gross, M. R. \& J. Repka, 1998. Stability with inheritance in the conditional strategy. Journal of Theoretical Biology 192: 445-453.

Gruzdeva, M. A., K. V. Kusishchin, E. D. Pavlov, A. G. Bush, N. V. Belova, M. P. Polyakov, A. M. Malyutina \& D. S. Pavlova, 2017. Morphophysiological patterns of life history strategy adoption in Dolly Varden Salvelinus malma in Kamchatka. Journal of Ichthyology 57: 688-705.

Harris, L. N., R. Bajno, C. P. Gallagher, I. Koizumi, L. K. Johnson, K. L. Howland, E. B. Taylor \& J. D. Reist, 2015. Life-history characteristics and landscape attributes as drivers of genetic variation, gene flow and fine-scale population structure in northern Dolly Varden (Salvelinus malma malma) in Canada. Canadian Journal of Fisheries and Aquatic Sciences 72: 1477-1493.

Harwood, L. A., S. Sandstrom \& E. Linn, 2009. Status of anadromous Dolly Varden (Salvelinus malma) of the Rat River, Northwest Territories, as assessed through sampling of the subsistence fishery (1995-2007). Canadian Manuscript Report of Fisheries and Aquatic Sciences 2891.

Hendry, A. P., T. Bohlin, B. Jonsson \& O. K. Berg, 2004. To sea or not to sea? Anadromy versus residency in salmonids. In Hendry, A. P. \& S. C. Stearns (eds), Evolution illuminated: salmon and their relatives. Oxford University Press, New York: 92-125.

Hindar, K. \& J. Nordland, 1989. A female Atlantic salmon, Salmo salar L., maturing sexually in the parr stage. Journal of Fish Biology 35: 461-463.

Howland, K. L., J. A. Babaluk, D. Chiperzak, R. F. Tallman \& G. Low, 2009. Variability in diadromous behavior of a northern coregonid based on scanning proton microprobe analysis of otolith strontium. In Haro, A. \& K. L. Smith, R. A. Rulifson, C. M. Moffitt, R. J. Klauda, M. J. Dadswell, R. A. Cunjak, J. E. Cooper, K. L. Beal \& T. S. Avery (eds), Challenges for diadromous fishes in a dynamic global 
environment. American Fisheries Society, Symposium 69, Bethesda, Maryland: 121-134.

Hutchings, J. A., 1986. Lakeward migrations by juvenile Atlantic salmon, Salmo salar. Canadian Journal of Fisheries and Aquatic Sciences 43: 732-741.

Jonsson, B., 1985. Life history patterns of freshwater resident and sea-run migrant brown trout in Norway. Transactions of the American Fisheries Society 114: 182-194.

Jonsson, B. \& N. Jonsson, 1993. Partial migration: niche shift versus sexual maturation in fishes. Reviews in Fish Biology and Fisheries 3: 348-365.

Jonsson, B., N. Jonsson, E. Brodtkorb \& P.-J. Ingebrigtsen, 2001. Life-history traits of brown trout vary with the size of small streams. Functional Ecology 15: 310-317.

Kendall, N. W., J. R. McMillan, M. R. Sloat, T. W. Buehrens, T. P. Quinn, G. R. Pess, K. V. Kuzishchin, M. M. McClure \& R. W. Zabel, 2014. Anadromy and residency in steelhead and rainbow trout (Oncorhynchus mykiss): a review of the processes and patterns. Canadian Journal of Fisheries and Aquatic Sciences 72: 319-342.

Koizumi, I., S. Yamamoto \& K. Maekwa, 2006. Female-biased migration of stream-dwelling Dolly Varden in the Shiisorapuchi River, Hokkaido, Japan. Journal of Fish Biology 68: 1513-1529.

Lehnert, S. J., K. A. Garver, J. Richard, R. H. Devlin, C. Lajoie, T. E. Pitcher \& D. D. Heath, 2018. Significant differences in maternal carotenoid provisioning and effects on offspring fitness in Chinook salmon colour morphs. Journal of Evolutionary Biology 31: 1876-1893.

Loewen, T. N., D. Gillis \& R. F. Tallman, 2010. Maturation, growth and fecundity of Arctic charr, Salvelinus alpinus (L.), life-history variants co-existing in lake systems of Southern Baffin Island, Nunavut, Canada. Hydrobiologia 650: 193-202.

Maekwa, K., T. Hino, S. Nakano \& W. W. Smoker, 1993. Mate preference in anadromous and landlocked Dolly Varden (Salvelinus malma) females in two Alaskan streams. Canadian Journal of Fisheries and Aquatic Sciences 50: 2375-2379.

Mangel, M. \& W. H. Satterthwaite, 2008. Combining proximate and ultimate approaches to understand life history variation in salmonids with application to fisheries, conservation, and aquaculture. Bulletin of Marine Science 83: 107-130.

McCart, P. J., 1980. A review of the systematics and ecology of Arctic char, Salvelinus alpinus, in the Western Arctic. Canadian Technical Report of Fisheries and Aquatic Sciences 935 .

McCart, P. \& H. Bain, 1974. An isolated population of Arctic char (Salvelinus alpinus) inhabiting a warm mineral spring above a waterfall at Cache Creek, Northwest Territories. Journal of the Fisheries Research Board of Canada 31: 1408-1414.

Mills, J. S., J. B. Dunham, G. H. Reeves, J. R. McMillan, C. E. Zimmerman \& C. E. Jordan, 2012. Variability in expression of anadromy by female Oncorhynchus mykiss within a river network. Environmental Biology of Fishes 93: 505-517.

Mochnacz, N. J., B. S. Schroeder, C. D. Sawatzky, \& J. D. Reist, 2010. Assessment of northern Dolly Varden, Salvelinus malma malma (Walbaum, 1792), habitat in Canada.
Canadian Manuscript Report of Fisheries and Aquatic Sciences 2926.

Moore, J.-S., T. N. Loewen, L. N. Harris \& R. F. Tallman, 2014. Genetic analysis of sympatric migratory ecotypes of Arctic charr Salvelinus alpinus: alternative mating tactics or reproductively isolated strategies? Journal of Fish Biology 84: $145-162$.

Morita, K., T. Tamate, M. Kuroki \& T. Nagasawa, 2014. Temperature-dependent variation in alternative migratory tactics and its implications for fitness and population dynamics in a salmonid fish. Journal of Animal Ecology 83: $1268-1278$.

Morrison, C. M., M. Kunegel-Lion, C. P. Gallagher, R. J. Wastle, E. V. Lea, T. M. Loewen, J. D. Reist, K. L. Howland \& K. B. Tierney, 2019. Decoupling of otolith and somatic growth during anadromous migration in a northern salmonid. Canadian Journal of Fisheries and Aquatic Sciences. https://doi.org/10.1139/cjfas-20180306.

Morrison, C., 2017. Life history strategies of northern form Dolly Varden (Salvelinus malma malma) in the western Canadian Arctic. M.Sc. thesis, Department of Biological Sciences, University of Alberta.

O'Connell, M. F. \& R. J. Gibson, 1989. The maturation of anadromous female Atlantic salmon, Salmo salar L., stocked in a small pond in urban St John's, Newfoundland, Canada. Journal of Fish Biology 34: 937-946.

Paton, C., J. Hellstorm, B. Paul, J. Woodhead \& J. Hergt, 2011. Iolite: freeware for the visualisation and processing of mass spectrometric data. Journal of Analytical Atomic Spectrometry 26: 2508-2518.

Pettersson, J. C. E., M. M. Hansen \& T. Bohlin, 2001. Does dispersal from landlocked trout explain the coexistence of resident and migratory trout females in a small stream? Journal of Fish Biology 58: 487-495.

Phillips, R. B., L. I. Gudex, K. M. Westrich \& A. L. DeCicco, 1999. Combined phylogenetic analysis of ribosomal ITS1 sequences and new chromosome data supports three subgroups of Dolly Varden char (Salvelinus malma). Canadian Journal of Fisheries and Aquatic Sciences 56: 1504-1511.

Pritchard, J. K., M. Stephens \& P. Donnelly, 2000. Inference of population structure using multilocus genotype data. Genetics 155: 945-959.

Prouzet, P., 1981. Observation d'une femelle de tacon de saumon atlantique (Salmo salar L.) parvenue à maturité sexuelle en rivière. Bulletin Français de Pisciculture 282: 16-19.

Quinn, T. P., L. A. Vøllestad, J. Peterson \& V. Gallucci, 2004. Influences of freshwater and marine growth on the egg size-egg number tradeoff in coho and Chinook salmon. Transactions of the American Fisheries Society 133: $55-65$.

R Core Team, 2017. R: a language environment for statistical computing. R foundation for statistical computing, Vienna, Austria. http://www.R-project.org.

Radtke, R. L., D. P. Fey, A. F. DeCicco \& A. Montgomery, 1996. Otolith microstructure in young-of-the-year Dolly Varden, Salvelinus malma, from American and Asian populations: resolution of comparative life history characteristics. Arctic 49: 162-169. 
Reist, J., 1989. Genetic structuring of allopatric populations and sympatric life history types of charr, Salvelinus alpinus/malma, in the western Arctic, Canada. Physiology and Ecology Japan 1: 405-420.

Reist, J. D., J. D. Johnson \& T. J. Carmichael, 1997. Variation and specific identity of char from Northwestern Arctic Canada and Alaska. American Fisheries Society Symposium 19: 250-261.

Reist, J. D., M. Power \& J. B. Dempson, 2013. Arctic charr (Salvelinus alpinus): a case study of the importance of understanding biodiversity and taxonomic issues in northern fishes. Biodiversity 14: 45-56.

Rideout, R. M., G. A. Rose \& M. P. M. Burton, 2005. Skipped spawning in female iteroparous fishes. Fish and Fisheries 6: $50-72$.

Rikardsen, A. H. \& J. M. Eliott, 2000. Variations in juvenile growth, energy allocation and life-history strategies of two populations of Arctic charr in North Norway. Journal of Fish Biology 56: 328-346.

Rosenfeld, J., T. Van Leeuwen, J. Richards \& D. Allen, 2015. Relationship between growth and standard metabolic rate: measurement artefacts and implications for habitat use and life-history adaptation in salmonids. Journal of Animal Ecology 84: 4-20.

Salisbury, S. J., C. Booker, G. R. McCracken, T. Knight, D. Keefe, R. Perry \& D. E. Ruzzante, 2018. Genetic divergence among and within Arctic char (Salvelinus alpinus) populations inhabiting landlocked and sea-accessible sites in Labrador, Canada. Canadian Journal of Fisheries and Aquatic Sciences 75: 1256-1269.

Sandstrom, S., L. Harwood \& K. Howland, 2009. Status of anadromous Dolly Varden charr (Salvelinus malma) of the Rat River, Northwest Territories, as assessed through mark-recapture and live-sampling at the spawning and overwintering site (1995-2007). Canadian Technical Report of Fisheries and Aquatic Sciences 2842.
Taylor, E. B. \& S. L. May-McNally, 2015. Genetic analysis of Dolly Varden (Salvelinus malma) across its North American range: evidence for a contact zone in southcentral Alaska. Canadian Journal of Fisheries and Aquatic Sciences 72: 1-10.

Thériault, V., L. Bernatchez \& J. J. Dodson, 2007. Mating system and individual reproductive success of sympatric anadromous and resident brook charr, Salvelinus fontinalis, under natural conditions. Behavioral Ecology and Sociobiology 62: 51-65.

Thorpe, J. E., M. Mangel, N. B. Metcalfe \& F. A. Huntingford, 1998. Modelling the proximate basis of salmonid life-history variation, with application to Atlantic salmon, Salmo salar L. Evolutionary Ecology 12: 581-599.

Tyndale, S. T., R. J. Letcher, J. W. Heath \& D. D. Heath, 2008. Why are salmon eggs red? Egg carotenoids and early life survival of Chinook salmon (Oncorhynchus tshawytscha). Evolutionary Ecology Research 10: 1187-1199.

van den Berghe, E. P. \& M. R. Gross, 1984. Female size and nest depth in coho salmon (Oncorhynchus kisutch). Canadian Journal of Fisheries and Aquatic Sciences 41: 204-206.

Verspoor, E. \& L. J. Cole, 1989. Genetically distinct sympatric populations of resident and anadromous Atlantic salmon, Salmo salar. Canadian Journal of Zoology 67: 1453-1461.

Wysujack, K., L. A. Greenberg, E. Bergman \& I. C. Olsson, 2009. The role of the environment in partial migration: food availability affects the adoption of a migratory tactic in brown trout Salmo trutta. Ecology of Freshwater Fish 18: 52-59.

Publisher's Note Springer Nature remains neutral with regard to jurisdictional claims in published maps and institutional affiliations. 